\title{
Computational modeling of fluidized bed behavior with agglomerates
}

\author{
Krister Jakobsen Rajan Jaiswal Nora C. I. S. Furuvik Britt M. E. Moldestad \\ Department of Process, Energy and Environmental Technology, University of South-Eastern Norway, Norway \\ Krister.Jako@gmail.com \{Rajan.Jaiswal, Nora.C.I.Furuvik, Britt.Moldestad\}@usn.no
}

\begin{abstract}
Fluidized bed reactors can be used for biomass gasification. The product from biomass gasification is syngas, which can be used for production of bio oil. The main challenge when using fluidized bed for gasification is ash melting and agglomeration of the bed material. Agglomeration of the bed material influences on the flow behavior in the fluidized bed reactor and thus affects the gasification efficiency. A Computational Particle Fluid Dynamic (CPFD) model is developed to predict the flow behavior in a fluidized bed gasifier. The CPFD model was validated against experimental data from a cold fluidized bed. The model was then tested against the results from a biomass gasifier, and a few modifications were needed. Glickman's scaling parameters were used to scale up from a lab-scale to a full-scale gasifier. Simulations using the modified model were performed to study the flow behavior in a full-scale gasifier with agglomerates. It was found that the CPFD model is capable of predicting the effect of agglomerates on flow behavior in a fluidized bed gasifier.
\end{abstract}

Keywords: biomass, gasification, ash, agglomeration, CPFD, Barracuda

\section{Introduction}

Biomass is considered a renewable energy source, and it is crucial to make the biomass conversion processes more energy effective. Biomass is converted via gasification into a syngas consisting of mainly $\mathrm{CO}$ and $\mathrm{H}_{2}$. Different technologies are used for gasification of biomass, and one of the most promising technologies is fluidized bed reactor. Fluidized bed reactors are used to ensure proper mixing of biomass and fluidizing gas, and thus increase the heat and mass transfer. Fluidized bed reactors are also very flexible when it comes to the type and quality of the biomass feed. The challenges when using fluidized bed gasifiers are ash melting and agglomeration of the bed material. Agglomeration may disrupt the flow behavior in the fluidized bed and thus affect the overall efficiency of the gasifier (Basu, 2013).

\section{Ash melting and agglomerates}

Ash melting is a big challenge in operation of biomass fluidized bed gasifiers. The amount of ash from biomass varies a lot depending on the type of biomass used. The typical content of ash in wood chips, straw and solid municipal waste is about $1 \mathrm{wt} \%, 8 \mathrm{wt} \%$ and $50 \mathrm{wt} \%$ respectively. However, even a small amount of ash can harm the gasification process, and it is therefore important to study how ash melting and agglomeration affect the flow behavior in a fluidized bed. Biomass such as grasses, demolition wood, and straw have a high potential to create agglomeration, fouling, and corrosion in a gasifier. (Basu, 2013)

The operating temperature for biomass fluidized bed gasifiers is usually kept in the range of $700-900^{\circ} \mathrm{C}$ to avoid ash melting. Ideally, the temperature should be increased to obtain a higher quality of the syngas and to avoid problems with tar. The ash melting temperature varies depending on the composition of the biomass. The melting temperature for spruce wood is $1170^{\circ} \mathrm{C}$, whereas the melting point for wheat straw is $915^{\circ} \mathrm{C}$ (Basu, 2013).

The most significant ash-forming elements in biomass are silica $(\mathrm{Si})$, potassium $(\mathrm{K})$, calcium $(\mathrm{Ca})$, magnesium $(\mathrm{Mg})$, aluminum $(\mathrm{Al})$, phosphor $(\mathrm{P})$, chlorine $(\mathrm{Cl})$, sodium $(\mathrm{Na})$ and sulphur $(\mathrm{S})$. (Balland et al., 2017; Furuvik et al., 2020). The ashforming elements are released from the biomass during the heating process. When the ash melts, the inorganic elements from the melted ash can create a sticky component, which functions as a glue between the ash and the sand particles, and agglomerates are formed. Figure 1 shows agglomerates which are created by melted biomass ash and sand particles. (Furuvik et al., 2019a; Furuvik et al., 2019b). The agglomerates are of various sizes and shapes, and may change the fluidization properties in a biomass gasifier significantly. An agglomerated bed creates instability in the bubble frequency and can cause fluid channeling. Agglomeration can also result in defluidized zones in the gasifier. In the most severe cases, particle agglomeration may lead to unscheduled shutdowns of the whole installation. (Öhman et al., 2000) 


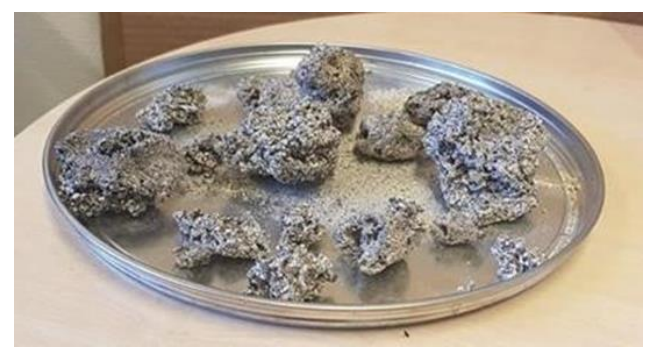

Figure 1. Agglomerates formed during gasification of biomass.

\section{Material and methods}

\subsection{Experimental set-up}

Two different experimental set-ups have been used in this study. One is a cold fluidized bed, where the fluid dynamic properties and flow behavior are studied. The other one is a biomass gasification reactor used to study the gasification yield at different operation conditions.

\subsubsection{Cold fluidized bed set-up}

The cold fluidized bed consists of a transparent cylindrical tube open to the atmosphere, and with a gas distributor plate at the bottom. The height and diameter of the cylinder are $140 \mathrm{~cm}$ and $8.4 \mathrm{~cm}$, respectively. Pressure transducers are installed along the height of the bubbling fluidized bed, and the distance between the transducers is $10 \mathrm{~cm}$. The model is shown in Figure 2. Experiments were performed with sand particles with density $2650 \mathrm{~kg} / \mathrm{m}^{3}$ as the bed material. A sieving analysis of the sand particles was performed and it was found that the particles had a size range of 300-700 $\mu \mathrm{m}$. The weighted mean particle diameter was calculated to $535 \mu \mathrm{m}$. An aspect ratio (bed height/bed diameter) of 2.5 was used in the experiments. Pressure drop in the bed was monitored and plotted versus the superficial air velocity.
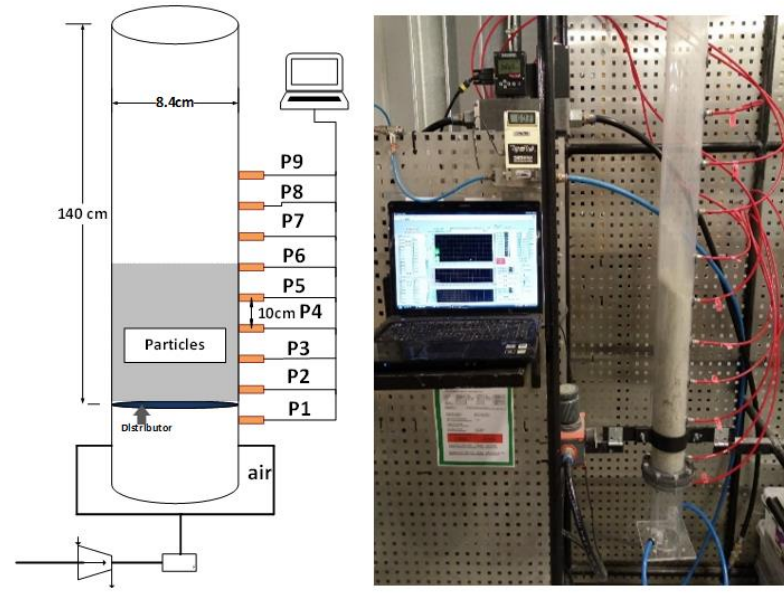

Figure 2. Experimental set-up; cold fluidized bed (Jaiswal et al, 2018).

\subsubsection{Biomass gasifier set-up.}

A lab-scale bubbling fluidized bed reactor with a feed capacity of $3-5 \mathrm{~kg} / \mathrm{h}$ was used for the experimental biomass gasification tests. A drawing of the reactor is presented in Figure 3. The experimental rig is composed of a feeding system, a fluidized-bed reactor, a preheating system for the fluidizing gas stream, a sampling line and an exhaust line. The biomass gasification rig is made of stainless steel. It has three electrical heating elements, which are installed externally. The gasifier is insulated with refractory material on the inside, and a $200 \mathrm{~mm}$ thick fiberglass layer on the outside to minimize the heat losses.

The feeding system consists of a silo followed by a cold and a hot screw feeder. The cold screw feeder conveys the feed from the silo to the hot screw feeder. The hot screw feeder transports the feed into the reactor. The reactor is a cylindrical vessel with an inner diameter of $0.1 \mathrm{~m}$ and a height of $1.0 \mathrm{~m}$. Air is used as the fluidizing agent, and flows through a pre-heater with a capacity of $18 \mathrm{~kW}$. The exhaust line goes from the top of the reactor and transports the product gases into a flare. At the top of the reactor, there is also a sampling line, where samples of the syngas are taken at regular intervals and analyzed in a gas chromatograph (GC SRI 8610C). Two experiments were performed at temperature $735^{\circ} \mathrm{C}$ using gas flow rates of 1.5 and 2 $\mathrm{kg} / \mathrm{h}$. The bed material was sand with a mean particle diameter of $367 \mu \mathrm{m}$ and density $2650 \mathrm{~kg} / \mathrm{m}^{3}$. The pressure drop over the particle bed was monitored.

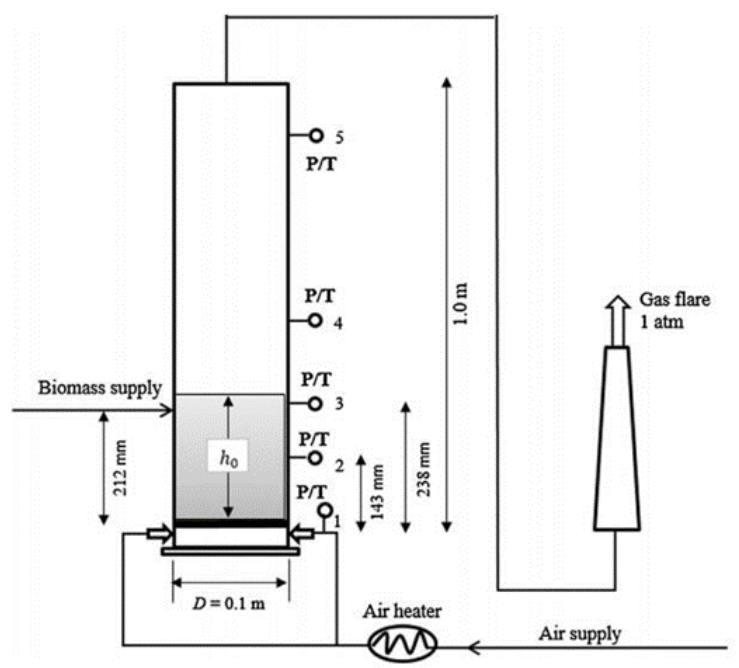

Figure 3. Experimental set-up; biomass gasifier.

\subsection{CPFD modelling}

Computational Particle Fluid Dynamics (CPFD) simulations are used to predict the minimum fluidization velocity and the flow behaviour in a cold fluidized bed and in a gasification reactor. The bed dimensions and the fluid and particle properties were the same as in the experimental tests. The CPFD model is developed using Barracuda VR. The CPFD numerical methodology 
incorporates the multi-phase-particle-in-cell (MP-PIC) method, where particles with the same properties are grouped into parcels and each parcel is represented by one computational particle (Snider, 2001; Amarasinghe, 2017). The gas phase and the particle phase are modelled using the Eulerian and the Lagrangian approaches respectively. Chladek et al. (2018) and Jayarathna et al. (2017) have described the transport equations in detail. Several drag models are available in Barracuda, and five of them were tested in this study. The five drag models are Ergun, Wen-Yu, Wen-Yu\&Ergun, Turton-Levenspiel and Nonspherical Haider-Levenspiel. The Ergun drag model is derived based on dense bed systems, and is only valid for gas volume fractions lower than 0.8. The Wen-Yu drag model (Wen and Yu, 1966) is developed based on a series of experiments performed by Richardson and Zaki in 1954. The experimental data are available in (Richardson and Zaki, 1997). The Wen-Yu correlation is valid when the internal forces between particles are negligible, meaning that the viscous drag forces dominate the flow behavior. The Wen-Yu drag coefficient is a function of the Reynolds number and the void fraction. Researchers have reported good agreement between experiments and simulations using the Wen-Yu drag model (Furuvik et al., 2019). The Wen-Yu \& Ergun drag model, is a combination of the two drag models. Wen-Yu's drag model is for dilute systems, and the Ergun drag model is for dense systems. This blend of drag models is controlled by the conditions set by the particle volume fraction and close pack volume fraction. Bandara et al. obtained good results when using the Wen-Yu \& Ergun drag model in simulation of a circulating fluidized bed system (Bandara et al., 2019). The Turton-Levenspiel model (Turton and Levenspiel, 1986) and the non-spherical HaiderLevenspiel model (Haider and Levenspiel, 1989; Chhabra et al., 1999) utilize a single particle drag function dependent on the fluid volume fraction.

\subsection{Scaling}

Fluidized bed reactors are operating under relatively high temperatures, and it is difficult to observe the flow behavior during operation. Therefore, cold fluidized beds are often used for these types of studies. A CFD or CPFD model can be developed and validated against experimental data from cold bed tests. The model can further be used for a biomass gasifier operating at high temperatures. The cold bed has to be scaled based on scaling rules to get the correct dimensions for the particles and reactor, and to fit with the flow behavior observed in the cold fluidized bed. Scaling rules are used to scale from cold to hot, and also for up-scaling from lab scale to pilot or industrial sized reactors. To obtain the fluid dynamic similarities between two reactors, properly developed scaling rules must be used.
The most commonly used scaling rules for fluidized bed reactors are the rules proposed by Glicksman (Glicksman, 1984; Glicksman

study, a simplified set of Glicks

parameters is used. This simplified set is known as Glicksman's viscous limit set of dimensionless parameters, and can be used when Reynolds number is less than 4 . The dimensionless numbers are: $\overline{U_{0}^{2}}, \frac{L}{d_{p}}, \frac{L_{1}}{L_{2}}, \frac{U_{0}}{U_{m f}}, \varphi$

$g \cdot L$

where $U_{0}$ is the operating gas velocity, minimum fluidization velocity,

diameter, $L$ is a reactor dimension (eg. diameter, height, bed height) and $\varphi$ is the sphericity.

\section{Results and discussion}

\subsection{Validation of CPFD model}

A CPFD model of the cold fluidized bed was developed and validated against experimental data.

was to find the drag model that gave the best fit experimental data. The grid resolution was set to cells, which resulted in a uniformly distributed grid of 9536 cells. Figure 4 shows the simulated pressure drop versus the superficial velocity for the different drag models.

The Turton-Levenspiel model fits well with the experimental results in the fixed bed area (velocities lower than $0.17 \mathrm{~m} / \mathrm{s}$ ), whereas the Wen

a good agreement with the experimental data in the fluidized regime (velocity between 0.16 and $0.20 \mathrm{~m} / \mathrm{s}$ ). A fluidized bed reactor will operate in the fluidized regime, and therefore it was decided to use the Wen drag function for the further validation of the CPFD model.

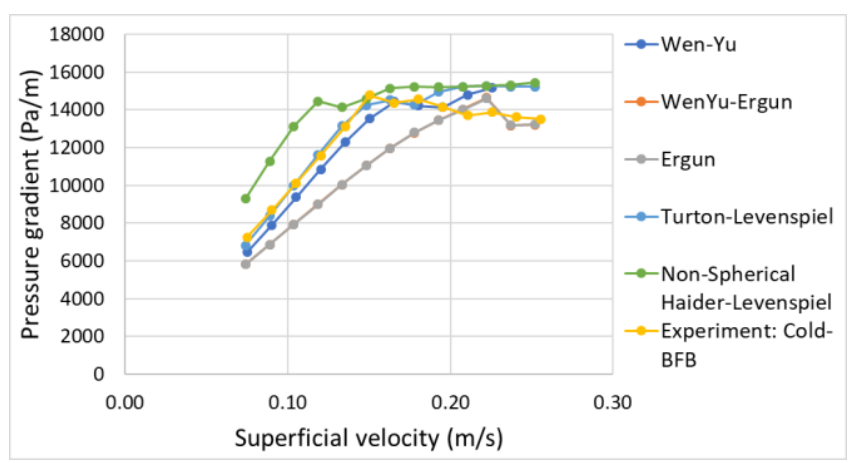

Figure 4. Comparison of different drag models against experimental data.

The next was to perform a grid resolution test. The number of cells was reduced from 12000 to 4000, and it was clear that using 4000 cells gave a significant deviation from the experimental results.

was also run with 20000 cells, but this did not give any significant difference compared to using 12000 cells. Since simulation with 20000 cells are more time 
consuming, the further simulations were run with 12000 cells. A time step dependency test was carried out, The time steps were changed from $0.001 \mathrm{~s}$ to $0.0001 \mathrm{~s}$. The results are presented in Figure 5. The plot shows that the CPFD model using Wen-Yu drag model, 12000 cells and time step $0.0001 \mathrm{~s}$ gives a good agreement with the experimental data. This model is further used to simulate agglomerates in an up-scaled fluidized bed reactor.

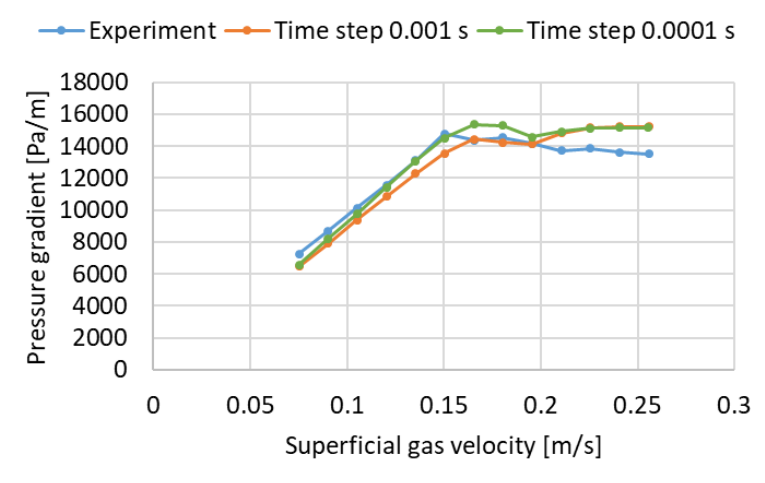

Figure 5. Comparison of simulations with different time step.

Figure 6 shows a comparison of the minimum fluidization velocity from the experiments and the simulation using the final model. The simulated minimum fluidization velocity is about $10 \%$ higher than the experimental. The deviation may be due to small differences in particle size distribution and the closed packed volume fractions. The drag model could have been tuned to fit the experimental data better. However, the model is capable of predicting the flow behavior in a fluidized bed with acceptable accuracy.

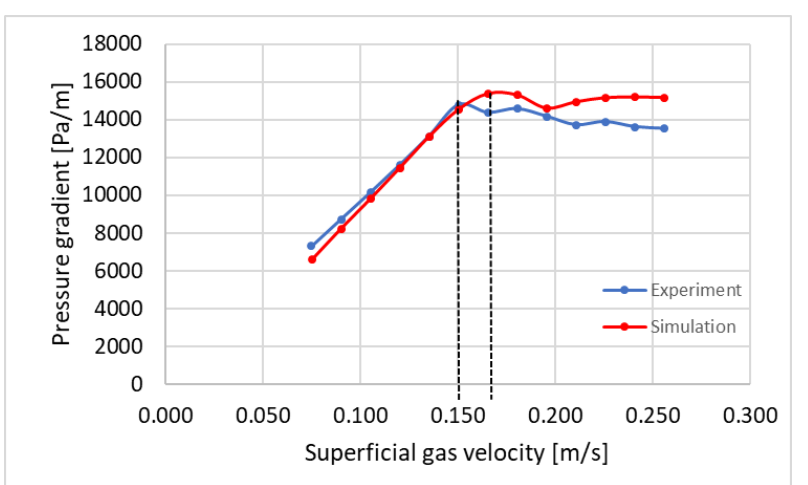

Figure 6. Comparison of minimum fluidization velocity. Dotted lines mark the minimum fluidization velocities.

The CPFD model was further tested against the results from the biomass gasifier, and it gave a good fit regarding the pressure drop over the bed at gas velocity $0.20 \mathrm{~m} / \mathrm{s}$.

\subsection{Scaled model}

The lab scale fluidized bed gasifier was up-scaled using Glicksman's viscous limit set of dimensionless parameters. Before doing the scaling, the diameter ratio of the two beds was set to 1:5, which means that the upscaled gasifier has a diameter of $0.5 \mathrm{~m}$. The reason why the geometry ratio was fixed, was to be able to simulate large agglomerates by using the same number of cells as in the simulation of the lab scale gasifier. In CPFD simulations of gas particle systems, the particle sizes cannot exceed the size of the computational cells. The scaling parameter $L / d_{p}$ had to be neglected to avoid unreasonably large sand particles to be used in the upscaled bed. The scaling parameters $\frac{U_{0}^{2}}{g \cdot L}, \frac{L_{1}}{L_{2}}, \frac{U_{0}}{U_{m f}}, \varphi$, were used for the up-scaling. The calculated parameters for the scaled and the lab scale gasifier are presented in Table 1. The highlighted values in the table are calculated based on the scaling rules.

Table 1: Parameters for the lab-scale and the up-scaled gasifier.

\begin{tabular}{|l|l|l|}
\hline Parameters & Lab-scale & Up-scaled \\
\hline $\mathrm{D}$ & $0.1 \mathrm{~m}$ & $0.5 \mathrm{~m}$ \\
\hline $\mathrm{H}_{\text {bed }}$ & $0.21 \mathrm{~m}$ & $\mathbf{1 . 0 5} \mathbf{~ m}$ \\
\hline $\mathrm{T}$ & $735^{\circ} \mathrm{C}$ & $735^{\circ} \mathrm{C}$ \\
\hline$\rho_{\mathrm{p}}$ & $2650 \mathrm{~kg} / \mathrm{m}^{3}$ & $2650 \mathrm{~kg} / \mathrm{m}^{3}$ \\
\hline$\rho_{\mathrm{g}}$ & $0.35 \mathrm{~kg} / \mathrm{m}^{3}$ & $0.35 \mathrm{~kg} / \mathrm{m}^{3}$ \\
\hline$\mu_{\mathrm{g}}$ & $0.000042 \mathrm{~Pa} \cdot \mathrm{s}$ & $0.000042 \mathrm{~Pa} \cdot \mathrm{s}$ \\
\hline $\mathrm{d}_{\mathrm{p}}$ & $367 \mu \mathrm{m}$ & $\mathbf{5 4 9} \boldsymbol{\mu m}$ \\
\hline$U_{0}$ & $0.153 \mathrm{~m} / \mathrm{s}$ & $\mathbf{0 . 3 4 2} \mathbf{~ m} / \mathbf{s}$ \\
\hline$U_{m f}$ & $0.051 \mathrm{~m} / \mathrm{s}$ & $\mathbf{0 . 1 1 4} \mathbf{~ m} / \mathbf{s}$ \\
\hline $\mathrm{d}_{\mathrm{aggl}}$ & - & $3-4 \mathrm{~cm}$ \\
\hline$\rho_{\mathrm{aggl}}$ & $1506 \mathrm{~kg} / \mathrm{m}^{3}$ & $1506 \mathrm{~kg} / \mathrm{m}^{3}$ \\
\hline
\end{tabular}

Simulation with pure sand particles and with sand particles together with agglomerates were performed. The operating air velocity was set constant to $0.15 \mathrm{~m} / \mathrm{s}$ in both simulations. In the simulation with agglomerates, agglomerates were fed continuously to the gasifier at a mass flow rate of $1.0 \mathrm{~kg} / \mathrm{s}$. The simulations were run for $90 \mathrm{~s}$, and the pressure drop over the bed versus superficial gas velocity was monitored. The aim of these simulations was to find the amount of agglomerates required to influence on the flow behavior in the bed. Figure 7 shows the comparison of the simulations with and without agglomerates. As can be seen from the figure, there is a drop in the pressure for the agglomerated bed already after $20 \mathrm{~s}(20 \mathrm{~kg}$ of agglomerates fed to the reactor). The reason can be that the average density of the bed decreases due to the presence of agglomerates having a lower density than the sand. The lower pressure drop can also be due to air channeling caused by the large agglomerates. Between 45 and $70 \mathrm{~s}$ the pressure drop over the agglomerated bed decreases gradually from $13500 \mathrm{~Pa} / \mathrm{m}$ to $12300 \mathrm{~Pa} / \mathrm{m}$. During this time interval, the mass of agglomerates in the bed has increased from $45 \mathrm{~kg}$ to $70 \mathrm{~kg}$, and it seems that the agglomerates have started to affect the flow behavior significantly. A higher concentration of agglomerates may lead to higher degree of channeling 
of the air, which again gives a lower pressure drop over the bed. The problem is that a large part of the air leaves the bed through channels, and that the remaining air is not sufficient to fluidize the bed. This can result in defluidized zones in the bed, low mass and heat transfer and uneven temperature in the bed. Zones with very high temperature can occur, which promotes ash melting and formation of more and bigger agglomerates. In the end, the bed will collapse, and the gasification process has to be shut down. Ash melting and agglomeration of bed material can also plug the reactor totally, and thereby lead to a dangerous situation. It is therefore crucial to ensure that the gasifier is always running in the fluidized regime.

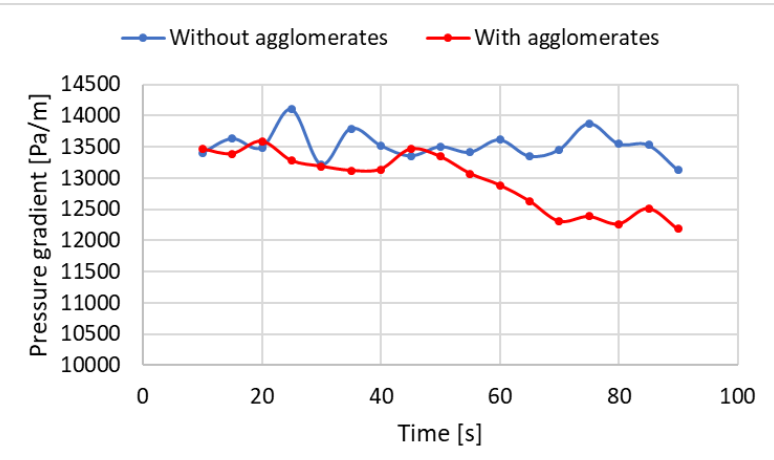

Figure 7. Simulation of gasifier with and without agglomerates. Gas velocity $0.15 \mathrm{~m} / \mathrm{s}$. Agglomerate feeding $1 \mathrm{~kg} / \mathrm{s}$.

Figure 8 shows the distribution of agglomerates (red) in the gasifier at time $0 \mathrm{~s}$ (no agglomerates), $60 \mathrm{~s} \mathrm{(60} \mathrm{kg} \mathrm{of}$ agglomerates and $90 \mathrm{~s}$ (90 kg of agglomerates). The agglomerates seems to segregate towards the bottom of the bed as the fraction of agglomerates increases. Figure 9 shows the flow behavior in the bed with $14 \mathrm{~kg}, 60 \mathrm{~kg}$ and $90 \mathrm{~kg}$ of agglomerates. The shape and frequency of the bubbles (areas with low particle fractions) change as the fraction of agglomerates increases. Also, the bubbles are getting more diffuse, meaning that the fraction of particles in the bubbles is increasing. This indicates that most of the air is leaving the bed in channels or through the emulsion.
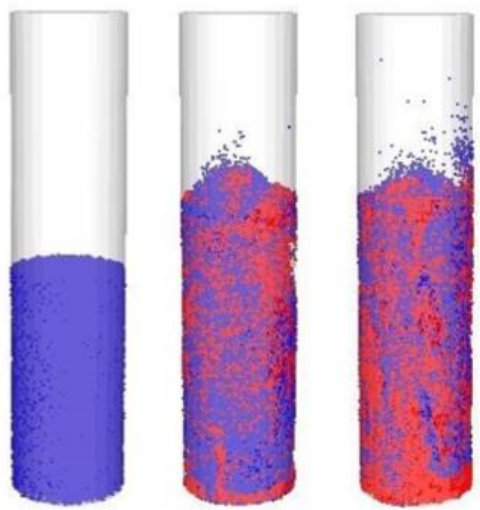

Figure 8. Distribution of agglomerates in the bed at time $0 \mathrm{~s}, 60 \mathrm{~s}$ and $90 \mathrm{~s}$. Sand is blue, agglomerates are red.

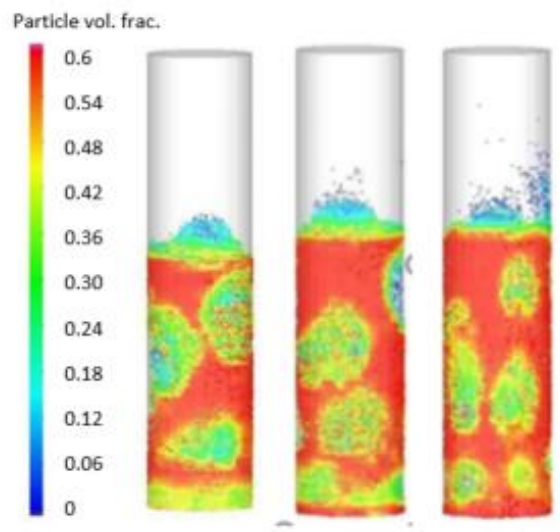

Figure 9. Flow behavior in agglomerated fluidized bed. Gas velocity $0.15 \mathrm{~m} / \mathrm{s}$, agglomerates 14,60 and $90 \mathrm{~kg}$.

The next simulations were run to predict the minimum fluidization velocity for pure sand and for sand with 60 $\mathrm{kg}$ ( $26 \%$ by volume) of agglomerates. The results are presented in Figure 10.

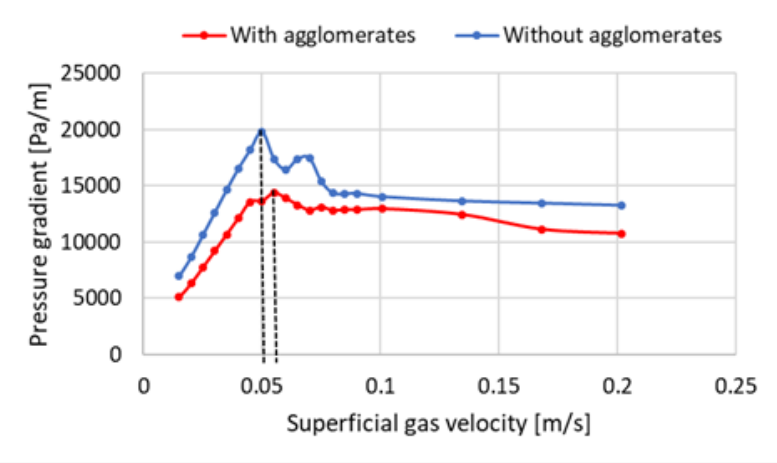

Figure 10. Minimum fluidization velocities (marked with dotted lines) for sand bed and agglomerated bed.

The pressure drop over the bed is significantly lower for the agglomerated bed than for the sand bed both in the fixed bed regime and in the fluidized regime. The minimum fluidization velocities are $0.05 \mathrm{~m} / \mathrm{s}$ for the sand bed and $0.055 \mathrm{~m} / \mathrm{s}$ for the agglomerated bed, which is significantly lower than the operating velocity of 0.15 $\mathrm{m} / \mathrm{s}$ in the previous simulations. It is also observed that the minimum fluidization velocity for the sand bed $(0.05$ $\mathrm{m} / \mathrm{s}$ ) is less than half of the scaled minimum fluidization velocity $(0.114 \mathrm{~m} / \mathrm{s})$. The reason is that the scaled minimum fluidization velocity is calculated from the Ergun's equation using the mean particle diameter. The minimum fluidization velocity very much depends on the particle size and the particle size distribution, and the smallest particles in a mixture influence significantly on the minimum fluidization velocity (Jayarathne and Halvorsen, 2009). In the simulations with Barracuda, the particle size distribution is included, and the simulations are therefore giving a more realistic value for the minimum fluidization velocity.

Figure 11 shows the distribution of the agglomerates (red) in the bed at minimum fluidization velocity $(0.055$ $\mathrm{m} / \mathrm{s}$ ) and at velocity $0.085 \mathrm{~m} / \mathrm{s}$. The volume fraction of 
agglomerates is $26 \%$. At minimum fluidization velocity, the agglomerates are uniformly distributed in the gasifier. However, when the gas velocity is increased to $0.085 \mathrm{~m} / \mathrm{s}$, the agglomerates segregates towards the bottom of the bed. Segregation of agglomerates can have unfortunate consequences for the gasification process, as it can lead to defluidized zones with high temperature at the bottom of the bed. This can trigger the formation of more and also larger agglomerates.

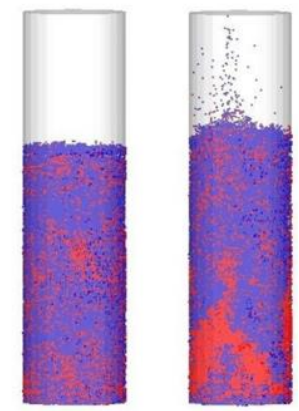

Figure 11. Distribution of agglomerates in the bed at gas velocity $0.055 \mathrm{~m} / \mathrm{s}$ and $0.085 \mathrm{~m} / \mathrm{s}$.

Figure 12 shows the comparison of the flow behavior in the bed without agglomerates (left) and with $26 \%$ agglomerates (right) at gas velocity $0.101 \mathrm{~m} / \mathrm{s}$. In the sand bed, the bubbles seem to be well distributed in the bed, whereas in the agglomerated bed it seems like the gas (bubbles) is channeling through the bed in the center. The channeling of the air will cause bad mixing and limited mass and heat transfer. It is crucial to run the gasifier at temperatures well below the ash melting temperature to avoid agglomeration of the bed material. It is also important to operate the gasifier well above the minimum fluidization velocity to avoid defluidization and segregation of the larger particles if agglomeration occurs. Reduction in pressure drop over the bed indicates that formation of agglomerates has occurred.

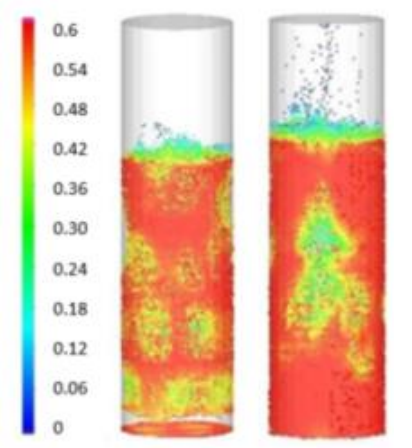

Figure 12. Distribution of particles in bed without agglomerates (left) and with agglomerates (right). Gas velocity $0.101 \mathrm{~m} / \mathrm{s}$.

\section{Conclusion}

The objective of this study was to develop a model to predict the flow behavior in a fluidized bed gasifier. A CPFD model is developed using the commercial software Barracuda VR. Experiments were performed using a cold model of a fluidized bed reactor to study the flow behavior and determine the minimum fluidization velocity. Additional experiments were performed in a lab-scale biomass gasifier $735^{\circ} \mathrm{C}$ to determine the pressure drop over the bed.

The CPFD model was first validated against experimental data from the cold fluidized bed. Grid resolution tests, tests with different time steps, and tests with different drag models were performed, and the final model gave good agreement with the experimental results. The average deviation between the experimental results and the simulations regarding pressure drop and minimum fluidization velocity was $6 \%$ and $10 \%$ respectively. The model was further tested against the results from the biomass gasifier, and it gave a good fit for the pressure drop over the bed at gas velocity 0.20 $\mathrm{m} / \mathrm{s}$. A few modifications were needed to be able to simulate an agglomerated fluidized bed gasifier. Glicksman's scaling rules were used to scale up the labscale gasifier to a full-scale gasifier. Simulations using the modified model were performed to study the flow behavior in a full-scale gasifier with agglomerates. The pressure drop over the bed decreased with increasing mass of agglomerates. The minimum fluidization velocity for the bed with 26 vol \% agglomerates was about $10 \%$ higher than for the sand bed. The bubble shape and bubble frequency changed with the fraction of agglomerates in the bed. This may be due to gas channeling and segregation of agglomerates. The developed CPFD model is capable of predicting the effect of agglomerates in a fluidized bed gasifier.

\section{Acknowledgements}

This work is funded by the Research Council of Norway, Program for Energy Research (ENERGIX). Project 280892 FLASH - Prediction of FLow behavior of ASH mixtures for transport biofuels in the circular economy.

\section{References}

C. E. Agu, C. Pfeifer, M. S. Eikeland, L. A. Tokheim, and B. M.E. Moldestad. Measurement and characterization of biomass mean residence time in an air-blown bubbling fluidized bed gasification reactor, Fuel, 253: 1414-1423, 2019.

W. S. Amarasinghe, C. K. Jayarathna, B. S. Ahangama, B.E.M. Moldestad, and L. A. Tokheim. Experimental study and CFD modelling of fluidization velocity for Geldart A, $\mathrm{B}$ and D particles. International Journal of Modelling and Optimization, 7(3): 152-156, 2017

M. Balland, K. Froment, G. Ratel, S. Valin, J. Roussely, R. Michel, J. Poirier, Y. Kara, and A. Galnares. Biomass ash Fluidized-Bed Agglomeration: Hydrodynamic Investigations. Waste Biomass, 8: 2823-2841, 2017.

J. Bandara, B. M. E. Moldestad, and M. S. Eikeland. Analyzing the Effects of Geometrical and Particle Size Uncertainty in Circulating Fluidized Beds using CPFD 
Simulation, Linköping Electronic Conference

Proceedings, 170: 182-189, 2019.

P. Basu. Biomass gasification, pyrolysis and torrefaction, 2nd ed. Elsevier Inc, 2013.

R Chhabra, L. Agarwal, and N. Sinha. Drag on nonspherical particles: an evaluation of available methods, Powder Technology, 101(3): 288-295, 1999.

J. Chladek, C. K. Jayarathna, and B. M. E. Moldestad. L. A. Tokheim, Fluidized bed classification of particles of different sixe and density, Chemical Engineering Science, 177: 155-162, 2018.

N. C. I. S Furuvik, R. Jaiswal, and B. M. E. Moldestad. Flow behavior in an agglomerated fluidized bed gasifier, International Journal of Energy and Environment, 10(2): 55-64, 2019a.

N. C. I. S Furuvik, R. Jaiswal, R. K. Thapa, and B. M. E. Moldestad. CPFD model for prediction of flow behavior in an agglomerated fluidized bed gasifier", International Journal of Energy Production and Management, 4(2): 105-114, 2019b.

N. C. I. S Furuvik, R. Jaiswal, and B. M. E. Moldestad. Experimental study of agglomeration of grass-pellets in fluidized bed gasification, WIT Transactions on Ecology and Environment, 246: 9-17, 2020 .

L. Glicksman. Scaling relationships for fluidized beds, Chemical Engineering Science, 39(9): 1373-1379, 1984.

L. Glicksman, M. Hyre, and P. Farrell. Dynamic similarity in fluidization, International Journal of Multiphase Flow, 20: 331-386, 1994.

A. Haider and O. Levenspiel. Drag coefficient and terminal velocityof sperical and nonspherical particles, Powder Technology, 58(1): 63-70, 1989.
R. Jaiswal, C. E. Agu, R. K. Thapa, and B. M. E. Moldestad. Study of fluidized bed regimes using Computational Particle Fluid Dynamics. Linköping Electronic Conference Proceedings, 153: 271-276, 2018

C. K. Jayarathna and B. M. Halvorsen. Experimental and computational study of particle minimum fluidization velocity and bed expansion in a bubbling fluidized bed. SIMS 50 Conference, Fredericia, Denmark: Technical University of Denmark (ISBN 978-87-89502-88-5)-285290, 2009.

C. K. Jayarathna, B. M. E.Moldestad, and L. A. Tokheim. Validation of results from Barracuda ${ }^{\circledR}$ CFD modelling to predict minimum fluidization velocity and pressure drop of Geldart A particles, Linköping Electronic Conference Proceedings, 138: 76-82, 2017.

J. F. Richardson and W.N. Zaki, Sedimentation and fluidization: Part I. Chemical Engineering Research and Design, 75: 82-100, 1997.

D. M. Snider. An incompressible three-dimensional multiphase particle-in-cell model for dense particle flows. Journal of Computational Physics, 170(2): 523-549, 2001.

R. Turton and O. Levenspiel. A short note on the drag correlation for spheres, Powder Technology, 47(1): 83-86, 1986.

C. Wen and Y. Yu. Mechanics of fluidization, Chemical Engineering Progress Symposium Series, 62: 100-111, 1966.

M. Öhman and A. Nordin. The Role of Kaolin in Prevention of Bed Agglomeration during Fluidized Bed Combustion of Biomass Fuels. Energy \& Fuels 14(3): 618-624, 2000. 